\title{
Analysis of Clay Stabilization Bearing Capacity with Matos and Cement for Subgrade in Kalimantan Pavement (Case Study of Beringin Village Soils)
}

\author{
Norseta Ajie Saputra ${ }^{1}$, Noviyanthy Handayani ${ }^{2}$ \\ Civil Engineering, Engineering and Informatics Faculty, Muhammadiyah University of \\ Palangkaraya, Jl. RTA. Milono Km. 1.5 Palangka Raya, Central Kalimantan ${ }^{1,2}$ \\ \{norseta.ajie@gmail.com ${ }^{1}$, vianthy84@yahoo.com²\}
}

\begin{abstract}
Beringin Village clay has low soil bearing capacity due to this reason, soil stabilization will be carried out using the Matos Stabilizer. It is expected can improve CBR and UCS values. The stabilization by mixing it with Matos and Cement. The proportion of the mixture is $1 \%, 3 \%, 5 \%$ Matos, and $12 \%$ cement in each percent of Matos. Research showed that the CBR value of the original soil was $4.61 \%$ and UCS was $2.00 \mathrm{~kg} / \mathrm{cm} 2$. Then, after stabilization with Matos $1 \%, 3 \%$ and $5 \%$ the CBR value respectively $34.55 \%, 49.07 \%$ and $40.55 \%$. While UCS values respectively are $3.98 \mathrm{~kg} / \mathrm{cm} 2,4.70 \mathrm{~kg} / \mathrm{cm} 2$ and $3.57 \mathrm{~kg} / \mathrm{cm} 2$. The result showed Matos 3\% gave CBR value increased significantly $112.15 \%$ and UCS decreased by $3.45 \mathrm{~kg} / \mathrm{cm} 2$. Generally, the addition of Matos and cement results increase the CBR value and decrease of UCS values.
\end{abstract}

Keywords: stabilization, matos, CBR, UCS.

\section{Introduction}

Soil is the foundation for a building or road construction [1]. Therefore, when the planning stage, one must consider is the original soil conditions in the field. Testing is needed to determine the bearing capacity of the sub-grade soil as a requirement for building roads. If the soil has a carrying capacity that satisfies the requirements, stabilization is not necessary. The requirements for the value of the carrying capacity of the soils to be categorized as good is if the CBR value based on field testing is $\geq 3 \%$, and the laboratory testing the value is $\geq 6 \%$. If soils do not meet these requirements can be categorized as having low bearing capacity. Soft soil can be categorized as soil with low bearing capacity because the CBR value is low, due to stabilization is necessary. Stabilization is the mixing of soil with certain materials to improve the technical properties of the soils. Or in other terms, soil stability is an attempt to change or improve the technical properties of the soils so that it meets certain technical requirements [2]. Generally, soil stabilization is carried out by two methods, namely mechanical or mechanical methods, and chemical stabilization or with added materials from factories.

In the study [3] using Matos $0 \%, 4 \%, 8 \%$, and $12 \%$ with the addition of $10 \%$ cement, the highest CBR value was obtained at the addition of $4 \%$ Matos, while for the UCS value the highest was the addition of $8 \%$ Matos. At Palangka Raya, one of the areas with soil conditions with low carrying capacity is Beringin village. Beringin Village is a strategic area through the 
northern route of the province of Central Kalimantan. Referring to these conditions, we have a desire to see the condition of the soils in the village of Beringin as an object of research. The research we did was how to stabilize the soils Beringin village with additives in the form of Matos combined with cement with a certain ratio.

\section{Literature review}

\subsection{Matos}

Matos is an additive that functions for freezing and stabilization of soil by physical and chemical processes. Matos is a fine powder material consisting of odorless inorganic mineral composition, has a $\mathrm{pH}$ of 8.37, a specific gravity of $2.35043 \mathrm{~g} / \mathrm{cm} 3$, and 1: 3 water solubility [3]. If we look at soil particles microscopically, then on the surface of the soils there is a thin layer of water, about $0.05 \mathrm{~mm}$ thick. This layer has tremendous strength, approximately $200,000 \mathrm{~kg}$ for every $1 \mathrm{~mm} 2$, to move this water layer, it takes a lot of energy. The main functions of the Matos Stabilizer are as follows:

a) Increasing the soil bearing capacity parameter to replace the base and subbase, as well as stabilization of the subgrade.

b) Reducing soil permeability, keeping soil water content to remain stable.

c) Maximizing the function of other stability materials such as cement and lime.

Apart from containing an inorganic mineral composition, Matos also contains a polymer which functions as follows:

a) Prevent liquefaction (flow) of soil in the sand and minimize the potential for liquefaction due to cyclic loads due to earthquakes,

b) Functioning in coastal and estuary reclamation works, because the soil is exposed to seawater and sulfates. And applications on cliffs where the soil is unstable and prone to landslides.

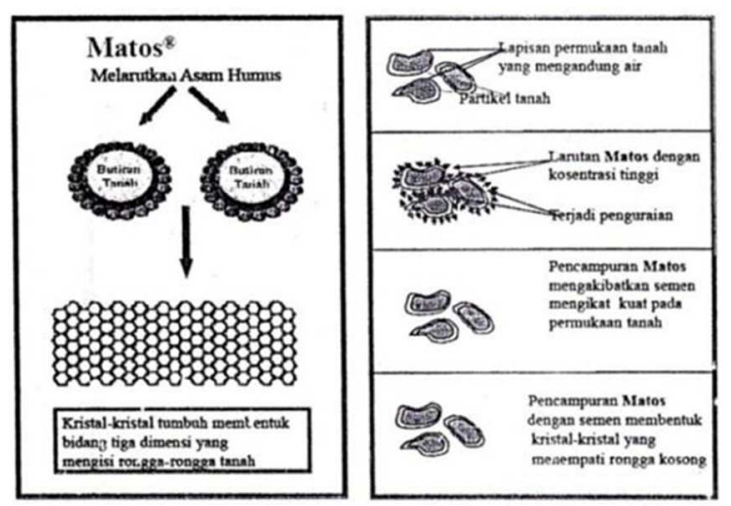

Fig. 1. Soil, Cement and Matos Reaction Process

\subsection{Portland cement}

Portland cement is an adhesive medium when it reacts with water. This adhesive medium then condensed and formed a hard mass. In the hydration process, the results of hydration will settle on the outside being divided into hydration gradually so that the volume decreases. This 
type of cement is ordinary Portland cement (Ordinary Portland Cement) used for buildings in general, where there are no special requirements [2]. Portland cement type I has advantages over other types of cement, in addition to being a fine powdered hydraulic material that can harden when mixed with water. The use of type I cement is widely used for general construction, such as construction of buildings that do not require special requirements, including residential buildings, multi-storey buildings, bridges, runways and highways [4].

\section{Methodology}

Soils samples in this study were taken from Beringin Village, Pahandut Seberang Subdistrict km.4 disturbing conditions. The soil samples were taken at a depth of approximately $20 \mathrm{~cm}$ as much as $150 \mathrm{~kg}$. The stages of the research carried out were started from taking soil samples in the field then continued with testing the physical and mechanical properties of the soil. Soil investigations were carried out to determine the classification of clay soils to be studied [5]. After the soil parameters are obtained, then a comparison of the CBR value of clay soil before and after mixing Matos and cement is carried out. The amount of cement used was $12 \%$ by weight of the mixture. For the test sample in this study, it is listed in the table below:

Table 1. Soil Sample Requirements

\begin{tabular}{|c|c|c|}
\hline No. & Testing & $\begin{array}{c}\text { Number of Sample } \\
\text { Requirements }\end{array}$ \\
\hline 1. & Water content & 3 \\
\hline \multirow[t]{6}{*}{2.} & Specific gravity & \\
\hline & a. Original Soil & 3 \\
\hline & b. Soil, Cement $12 \%$ and Matos $0 \%$ & 3 \\
\hline & c. Soil, Cement $12 \%$ and Matos $1 \%$ & 3 \\
\hline & d. Soil, Cement $12 \%$ and Matos $3 \%$ & 3 \\
\hline & e. Soil, Cement $12 \%$ and Matos $5 \%$ & 3 \\
\hline 3. & Grain Distribution & 3 \\
\hline 4. & Plastic Limits & 3 \\
\hline 5. & Liquid Limit & 3 \\
\hline \multirow[t]{6}{*}{6.} & Proctor Compaction & 3 \\
\hline & a. Original Soil & 5 \\
\hline & b. Soil, Cement $12 \%$ and Matos $0 \%$ & 5 \\
\hline & c. Soil, Cement $12 \%$ and Matos $1 \%$ & 5 \\
\hline & d. Soil, Cement $12 \%$ and Matos $3 \%$ & 5 \\
\hline & e. Soil, Cement $12 \%$ and Matos $5 \%$ & 5 \\
\hline \multirow[t]{6}{*}{7.} & $\mathrm{CBR}$ & \\
\hline & a. Original Soil & 3 \\
\hline & b. Soil, Cement $12 \%$ and Matos $0 \%$ & 3 \\
\hline & c. Soil, Cement $12 \%$ and Matos $1 \%$ & 3 \\
\hline & d. Soil, Cement $12 \%$ and Matos $3 \%$ & 3 \\
\hline & e. Soil, Cement $12 \%$ and Matos $5 \%$ & 3 \\
\hline \multirow[t]{6}{*}{8.} & UCS & \\
\hline & a. Original Soil & 1 \\
\hline & b. Soil, Cement $12 \%$ and Matos $0 \%$ & 1 \\
\hline & c. Soil, Cement $12 \%$ and Matos $1 \%$ & 1 \\
\hline & d. Soil, Cement $12 \%$ and Matos $3 \%$ & 1 \\
\hline & e. Soil, Cement $12 \%$ and Matos $5 \%$ & 1 \\
\hline
\end{tabular}




\section{Results and Discussion}

After conducting research at the Geotechnical Laboratory of the Faculty of Engineering, UM Palangkaraya, the characteristics of the clay soil in Beringin village, Palangka Raya city based on each sampling can be seen in the table below.

Table 2. Characteristics of Clay Village of Beringin Village

\begin{tabular}{lcc}
\hline \multicolumn{1}{c}{ Type of Testing } & Unit & Result \\
\hline Passed Filter No.200 & $\%$ & 81.08 \\
\hline Liquid Limit (LL) & $\%$ & 36.20 \\
\hline Plastic Limit (PL) & $\%$ & 24.33 \\
\hline Plasticity Index (PI) & $\%$ & 11.87 \\
\hline Specific gravity & - & 2.70 \\
\hline Maximum dry fill weight & $\mathrm{gr} / \mathrm{cm} 3$ & 1.56 \\
\hline Optimum water content & $\%$ & 24.60 \\
\hline Development & $\%$ & 6.40 \\
\hline CBR & $\%$ & 4.61 \\
\hline UCS & $\mathrm{kg}$ & 1.60 \\
\hline \multicolumn{3}{c}{ Source: Research Results, (2019) } \\
\hline
\end{tabular}

The identification result of the original soil is a description of the properties of the soil. These characteristics will be compared to several theories, existing regulations / research that has been conducted. This can be seen in Table 3 below.

Table 3. Results of Original Soil Identification

\begin{tabular}{cccc}
\hline $\begin{array}{c}\text { Theory/ } \\
\text { regulations }\end{array}$ & Requirements & Test result & Conclusion \\
\hline \multirow{4}{*}{ AASHTO } & PI $>11 \%$ & PI average $=11.87 \%$ & Classification A-6 CL / \\
& LL $>41 \%$ & LL Average $=36.20 \%$ & inonic clay with \\
& Sieve Analysts $>35 \%$ & Passed Filter no.200 & moderate plasticity \\
& pass no.200 & $80.08 \%$ & \\
UL $<50 \%$ & LL $=36 \%$ & CL / Inorganic clay \\
USCS & Filter analysis $>50 \%$ & Passing Filter no.200 & with low to medium \\
passed no. 200 & $80.08 \%$ & plasticity \\
Hardiyatmo & $2.68<$ Gs $<2.75$ & Gs average $=2.70$ & Contains Inorganic \\
$(2006)$ & & & Clays \\
\hline
\end{tabular}

Source: Research Results (2019)

\subsection{Relationship of Specific gravity, CBR and UCS of Soil on Mixed Soil Matos and Cement}

Based on the results of the tests that have been carried out, it can be done grouping the specific gravity and CBR values of the original soil and the mixed soil and cement mix that have been varied. The test results are set out in the table below:

Table 4. Comparison of Specific gravity, CBR and UCS values

\begin{tabular}{llccc}
\multicolumn{5}{c}{ Table 4. Comparison of Specific gravity, CBR and UCS values } \\
\hline No. & \multicolumn{1}{c}{ Soil Conditions } & Specific gravity & CBR (\%) & UCS $\left(\mathbf{k g} / \mathbf{~ c m}^{\mathbf{2}}\right)$ \\
\hline 1. & Original Soil & 2.69 & 4.61 & 2.00 \\
2. & Soil, Cement 12\% and Matos 0\% & 2.68 & 41.78 & 4.00 \\
3. & Soil, Cement 12\% and Matos 1\% & 2.64 & 34.55 & 3.98 \\
4. & Soil, Cement 12\% and Matos 3\% & 2.58 & 49.07 & 4.70
\end{tabular}




\begin{tabular}{lcccc}
\hline No. & Soil Conditions & Specific gravity & CBR (\%) & UCS (kg / $\left.\mathbf{~ m}^{\mathbf{2}}\right)$ \\
\hline 5. & Soil, Cement $12 \%$ and Matos 5\% & 2.69 & 112.15 & 3.45 \\
\hline \multicolumn{5}{c}{ Source: Research Results, (2019) }
\end{tabular}

Based on the value in the comparison table for the specific gravity and CBR values above, it can be stated in the curve image below.

\section{Comparison of Specific gravity to Matos admixture}

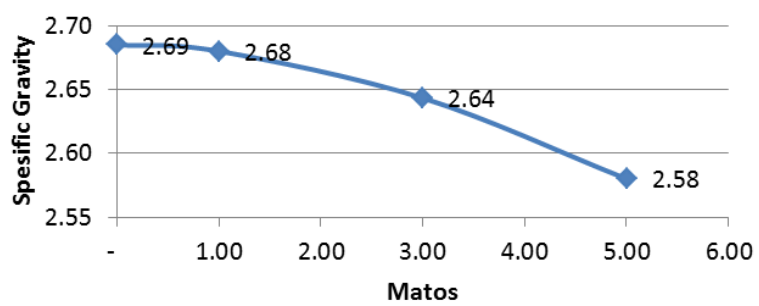

Fig. 2. Graph of Specific gravity Against Matos Increase (Research Results, 2019)

From the test results in Figure From the image above, it can be seen that the value of specific gravity (Gs) decreases with increasing mixture of cement and matos. The value of specific gravity (Gs) is at the lowest point in the cement mixture of $12 \%$ and $5 \%$ Matos. Meanwhile, the comparison of CBR and UCS values can be stated in Figures 4 and 5 below.

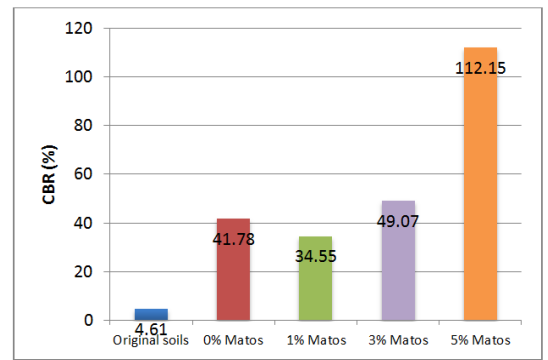

Fig. 3. CBR value comparison curve (Research Results, 2019)

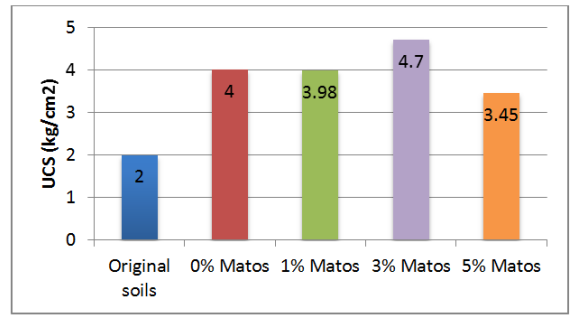

Fig. 4. Curve value comparison of UCS values (Research Results, 2019)

In Figure 4, it can be seen that the CBR value increases with increasing matos mixture. It can be seen that the non-matos mixture obtained CBR of $41.78 \%$. then the addition of $1 \%$ 
matos was able to provide CBR values up to $34.55 \%$ and decreased from the non-matos mixture. Then the addition of $3 \%$ matos the CBR value increased to $49.07 \%$ and at the addition of $5 \%$ matos the CBR value increased to $112.15 \%$. The increase in CBR value at a percentage of $1 \%, 3 \%, 5 \%$ was due to the addition of certain cement and matos that could reduce the development and reduce the moisture content so that the bonded particles would stick together and harden. While in Figure 5 it can be seen that the UCS value obtained is irregular where the lowest value is obtained in the original soil conditions and the highest value is obtained at the addition of 3\% matos. From the test results recorded on the curves in Figures 4 and 5 it can be concluded that. CBR and UCS values on stabilization testing do not have a significant correlation [6]. It is proven in the stabilization test using cement and matos. The maximum CBR value of $112.15 \%$ is obtained in a mixture of $5 \%$. While the maximum UCS value of $470 \mathrm{~kg} / \mathrm{cm}^{2}$ was obtained in a $3 \%$ matos mixture [7].

\section{Conclusions and Suggestions}

\subsection{Conclusions}

The conclusions that can be drawn from the research that has been done are as follows:

a) The specific gravity and CBR values of the original soil were obtained at 2.69 and $4.61 \%$, respectively.

b) The density of soil mixed with $12 \%$ cement will decrease along with the increase in the number of matos.

c) In the original soil mixing composition, $12 \%$ cement and $0 \%$ matos obtained CBR values of $41.78 \%$ and UCS $4.00 \mathrm{~kg} / \mathrm{cm}^{2}$. In the mixture composition of $12 \%$ cement and $1 \%$ matos, the CBR value was $34.55 \%$ and UCS $3.98 \mathrm{~kg} / \mathrm{cm}^{2}$, then in the original soil mixing composition, $12 \%$ cement and $3 \%$ matos increased with a CBR value of $49.07 \%$ and UCS $4.70 \mathrm{~kg} / \mathrm{cm}^{2}$, then in the composition of mixing the original soil, $12 \%$ cement and $5 \%$ matos increased with a CBR value of $112.15 \%$ and decreased with a UCS value of $3.54 \mathrm{~kg} / \mathrm{cm}^{2}$.

d) It can be concluded that with the addition of $12 \%$ cement and variation of Matos, it is known that the CBR value is inversely proportional to the specific gravity value obtained. Where the CBR value will increase with the addition of Matos while the specific gravity value will decrease with the addition of Matos.

e) In addition, it can also be concluded that the CBR and UCS values in this study do not have a significant correlation.

\subsection{Suggestion}

Suggestions that can be given from the results of the research that have been done are as follows: Increase the number of soil samples and different soil types; For further research, it can be considered to correlate the PI value to the CBR value stabilized with Matos.

\section{Acknowledgements}

This research can be carried out because of the assistance of the Civil Engineering Study Program, Muhammadiyah University of Palangkaraya. 


\section{Reference}

[1] Sukirman,S. 2015. Dasar-dasar Perencanaan Geometrik Jalan, , Jakarta : Karya Manunggal Lithomas.

[2] Hardiyatmo, H.C. 2010. Stabilisasi Tanah Untuk Perkerasan Jalan, Yogyakarta : Gajah Mada University Press,

[3] Janah, R. N., Respati, R., \& Saputra, N. A. (2017). Pengaruh Matos Terhadap Stabilisasi Tanah Lempung Desa Mintin Dengan Semen Untuk Perkerasan Jalan Raya. Media Ilmiah Teknik Sipil, 6(1), 01-07. https://doi.org/10.33084/mits.v6i1.1455

[4] Hatmoko, J. T., \& Lulie, Y. (2007). UCS Tanah Lempung Ekspansif Yang Distabilisasi Dengan Abu Ampas Tebu Dan Kapur. Jurnal Teknik Sipil Universitas Atma Jaya Yogyakarta, 8(1), 64-77. http://jurnalmesin.petra.ac.id/index.php/uaj/article/view/17523

[5] Das, B.M. 1995. Mekanika Tanah (Prinsip-prinsip Rekayasa Geoteknis). Jakarta : Erlangga

[6] Bowles,J.E, 1993. Sifat-sifat fisik dan Geoteknis Tanah, Jakarta : Erlangga

[7] Predikson, 2015. Korelasi Nilai CBR dan UCS Tanah Lempung Palangka Raya Distabilisasi Pasir dan Semen, Penelitian Skripsi, Program Studi Teknik Sipil, Universitas Muhammadiyah Palangkaraya. 